УДК 294.3

DOI 10.31554/978-5-7925-0573-5-2019-2-238-247

П. Е. Янгутов ${ }^{1}$

БУДДОЛОГИЧЕСКИЕ ИССПЕДОВАНИЯ

ИНСТИТУТА МОНГОИОВЕДЕНИЯ, БУДДОИОГИИ

И ТИБЕТОПОГИИ СО РАН В КОНТЕКСТЕ МИРОВЫХ БУДДОЛОГИЧЕСКИХ ИССЛЕДОВАНИЙ

\author{
L. E. Yangutov
}

\title{
BUDDHIST RESEARCHES OF THE INSTITUTE FOR MONGOLIAN, BUDDHIST AND TIBETAN STUDIES OF THE SB RAS IN THE CONTEXT OF WORLD BUDDHIST STUDIES
}

Буддология представляет собой науку, которой очень трудно и сложно дать однозначное определение. В энциклопедии «Философия буддизма» говорится о том, что «буддология 1) в европейской науке - комплекс буддийских учений о Будде, буддах, их свойствах, силах и т. п.; 2) в российском востоковедении с 1930-1950-х - вся область научных исследований о различных сторонах и аспектах буддизма» [2011: 181].

Вся сложность определения буддологии как науки заключается в множественности ее предметов. Объект изучения один - это буддизм. Наиболее значимыми предметами исследования выступают письменные источники буддизма (источниковедение); история буддизма; учение буддизма (философия, сотериология, психология, этика, эстетика буддизма и т. п.); религиозная практика буддизма; образование буддизма; искусство буддизма; место и роль буддизма в общественно-политических процессах современного мира. Вся эта предметная область буддологии не всегда связана между собой единой концептуальной канвой и во многом представляет собой конгломерат дисциплин.

Кроме предметного различения, существует различие буддизма и по ареалам его распространения, которые принято делить на национальный буддизм - индийский, китайский, тибетский, японский, монгольский, бурятский и т. д. Это дало повод к появлению концепции о «множественности буддизма». Против такого деления выступил профессор Самдонг Римпоче на международной конфе-

${ }^{1}$ Янгутов Леонид Евграфович - доктор философских наук, профессор, главный научный сотрудник Федерального государственного бюджетного учреждения науки «Институт монголоведения, буддологии и тибетологии Сибирского отделения Российской академии наук», г. Улан-Удэ, Россия. E-mail: yanguta@mail.ru.

2 Доклад зачитан на ученом совете ИМБТ СО РАН 27 января 2015 г. 
ренции «Буддизм в изменяющемся мире», прошедшей в Улан-Удэ в 2015 г. (см.: [Самдонг 2015: 18]).

Очевидно, в таком случае уместно говорить не о национальном виде буддизма, а о трех региональных моделях, имеющих определенные различия в своей философско-сотериологической парадигме: индийской (материнской), китайской и тибетской. Эти модели, в свою очередь, получили распространение в других странах: китайская - в Японии, Корее, Вьетнаме, тибетская - в Монголии, Бурятии, Калмыкии, Туве. В своем докладе я остановлюсь на трех моделях, не затрагивая конкретно национальные формы.

На сегодняшний день существует огромное количество буддологических работ, даже перечисление названий которых составило бы десятки томов. Но целью моего доклада является не характеристика этих исследований, она прозвучала в докладе И. С. Урбанаевой ${ }^{1}$. Цель моего доклада - рассмотреть те тенденции, которые сложились в мировой и российской буддологии в контексте названной выше предметной области буддологической науки, и определить, какую нишу в ней занимают исследования нашего института.

В докладе И. С. Урбанаевой были намечены основные буддологические центры, университеты и ученые. Не повторяя их, выделю из них ведущие страны, которые задают сегодня исследовательские перспективы буддологической науки. Это США, Германия, Англия, Франция, Индия, Китай, Япония, Монголия, Россия.

Сама буддологическая наука зародилась сравнительно недавно, она началась в середине XIX в. Для науки это сравнительно молодой возраст. Ее становление связано с именами Эжена Бюрнуфа (1801-1852) - французского ученого, создавшего первый систематический очерк о буддизме «Введение в изучение индийского буддизма», и Макса Мюллера (1823-1900) - немецкого ученого, благодаря которому в научный оборот был введен текст самой известной буддийской сутры «Дхаммапады». В числе пионеров буддологических исследований были и российские ученые - Исаак Якоб Шмидт (1779-1847), Осип Михайлович Ковалевский (1801-1878) и Петр Иванович Кафаров (Палладий, 1817-1878). (О ранней истории буддологической науке см.: [Лысенко 1994: 24-31].) Российские ученые, в отличие от западноевропейских, открывших буддизм через палийские каноны, обратили свое внимание на его монгольские, тибетские и китайские тексты. Особая заслуга в этом принадлежит В. П. Васильеву.

С самого начала зарождения буддологии в центре внимания были три предмета - источниковедение, учение, история буддизма. Эти предметные области составляют каркас классической буддологии. Они и станут главным объектом нашего внимания. Источниковедение составляет фундамент классической буддологии, оно определяет направление исследования в других предметных областях буддизма, в первую очередь в такой предметной области, как учение буд-

${ }^{1}$ Научный доклад И. С. Урбанаевой «О современном состоянии и основных направлениях исследований по буддизму в мировой буддологии» зачитан на ученом совете ИМБТ 2 декабря 2014 г. 
дизма. И именно по уровню развития источниковедческих работ судят об уровне буддологических исследований.

В исследовании источников вначале первенство было за европейской наукой (Германия, Франция, Англия). Объектом европейского источниковедения стали сочинения на пали и санскрите. Российские ученые, как уже было сказано, с самого начала обратили внимание на китайские, тибетские, монгольские источники, чуть позже на санскрит. Сегодня лидирующие позиции в области классической буддологии занимают университеты и буддологические центры США (о причинах такого возвышения говорилось в докладе И. С. Урбанаевой). Не повторяя их, отмечу ведущие из них - это Колумбийский, Гарвардский, Калифорнийский, Чикагский, Принстонский университеты, также университет Виргинии и Американский институт буддологических исследований.

В американских университетах наметилась следующая тенденция: имевшее большую значимость в Европе исследование буддизма на пали и санскрите ушло на второй план, уступив место китайским и тибетским источникам. Ранее, в 1970-х гг., большой популярностью пользовались источники на китайском языке, благодаря работам Судзуки, который познакомил западный мир с дзэн-буддизмом - особенно это касается Калифорнийского университета в Беркли, Принстонского университета в Нью-Джерси, Нью-Йоркского университета. Особое внимание привлекали чаньские тексты, которые обусловили новый бум, связанный с интересом к философии, психологии, психофизической религиозной практике буддизма. Однако такой интерес постепенно сошел на нет, и на их место пришли тибетские источники. Это во многом объясняется деятельностью Далайламы на поприще научных исследований буддизма, а также тибетских ученых и монахов, активно занимающихся переводом тибетских источников на английский язык, их публичной, научной и просветительской деятельностью.

Что касается буддологических исследований Европы, базирующихся на источниковедческой традиции, то они заметно уступают американским, несмотря на то что буддология началась в Европе. Здесь сложилось несколько классических школ. Англо-американскую школу представляли супруги Рис-Дэвидс, Г. Ольденберг, Э. Конзе. Супруги Рис-Дэвидс и Ольденберг работали с литературой на пали, полагая, что эти тексты передают истинное учение Будды. Конзе работал с санскритскими источниками, через которых одним из первых из европейцев познакомил научное сообщество с текстами Праджняпарамиты. Среди буддологов долго не стихали споры об аутентичности текстов на пали или санскрите.

Следующей классической школой считается франко-бельгийская, представителями которой являются Луис де ла (Вале) Пуссен, Жан Пжилусски, Сильве Леви, Этьен Ламотт. Они исследовали буддийские источники на санскрите, Луис де ла Пуссе исследовал Абхидхарма-кошу, составляя в этом конкуренцию российской школе буддологии, возглавляемой Ф. И. Щербатским (см.: [Лысенко 1994: 32-40]). 
В орбиту внимания европейских исследователей постепенно входили китайские и тибетские источники. Однако стоит отметить, что внимание к китайским источникам, по сравнению с американским, было намного сдержанней. Здесь стоит выделить фундаментальные справочные издания - «Каталог китайской Трипитаки», составленный Б. Нандзё и опубликованный Оксфордским университетом, немецко-китайский «Словарь буддийских терминов», составленный Хакманом и изданный в Лейдене, англо-китайский словарь буддийских терминов, составленный Эйтелем и изданный в Лондоне. Сегодня в Европе сохраняется интерес к китайским источникам, но тем не менее, как и в США, все более пристальное внимание уделяется тибетским источникам.

Относительно европейских университетских центров можно сказать, что в прошлом наиболее известные европейские программы изучения буддизма имелись в Оксфорде и Кэмбридже, в Центре азиатских и африканских исследований Лондонского университета, в Гумбольдтском и Боннском университетах, в Сорбонне. Сегодня ведущие позиции в буддологии занимают Гамбургский и Венский университеты, Австрийская академия наук, Лондонский университет, Оксфорд, Бристольский, Лейденский университеты, Университет Неаполя.

Изучение источников на тибетском языке занимает большое место в Индии, Китае, Монголии. В Китае буддологические интересы в равной степени сосредоточены на тибетологическом и китаеведном направлениях. Причем следует обратить внимание на тот факт, что тибетологические исследования в Китае во многом инициируются со стороны китайских властей. Примером тому является издание Исследовательским центром китайской тибетологии тибетского буддийского канона Ганджур (108 томов, Bka' 'gyur, 2006-2008) и Данджур (124 тома, Bstan 'gyur, 1994-2007), где каждый том имеет в среднем от 1100 до 1500 страниц. Грандиозная работа по опубликованию всего корпуса тибетского буддийского канона сопровождалась выпуском в большом количестве тибетских и монгольских источников по истории буддизма.

В 1982 г. Госсовет КНР утвердил издательский комитет по изданию буддийского канона на китайском языке, в 1992 г. в Исследовательском центре китайской тибетологии был создан комитет по изданию буддийского канона на тибетском языке. С 1994 по 2007 г. Центр китайской тибетологии опубликовал 124 тома критического издания тибетского Данджура (1994-2007), каждый из которых имеет в среднем от 1100 до 1500 страниц [Bstan 'gyur]. С 2006 по 2008 г. было выпущено 108 томов Ганджура [Bka' 'gyur]. Масштабная работа по опубликованию всего корпуса тибетского буддийского канона сопровождается также выпуском в большом количестве сочинений буддийских мыслителей Индии и Тибета, например, «Основы Тантры - Бодхисаттва Виная и Тантраяна Виная» Цзонхавы [Rje tsong kha pa 1999], «Детальный комментарий на Мадхьямикакарика» Нагарджуны [Dpal mgon 'phags pa klu sgrub, 1988]. Издаются и современные исследования ученых по самым различным аспектам тибетского буддизма. 
В 1981 г. в рамках Тибетской академии общественных наук был создан Тибетский институт религий, в 1984 г. - факультет буддологии и кафедра религии при Тибетском университете. В 1983 г. под эгидой тибетского отделения Китайской буддийской ассоциации открыт Тибетский институт буддизма. В 1987 г. Панчен-ламой образована в Пекине Высшая буддийская академия для тибетских тулку. Тибетские монахи обучаются также в Институте религий при Китайской академии общественных наук и в Институте Южной Азии при Пекинском университете. В 1981 г. после 15-летнего перерыва вновь открылось тибетское отделение Китайской буддийской ассоциации. Религиозными образовательными структурами среди них являются Тибетский институт буддизма и Высшая буддийская академия Китая.

Большое значение в Китае придается и собственно китайским источникам. Свидетельство этому - многотомная Трипитака, «Да чжэн синь и да цзан цзин», включающая полный свод сутр, шастр, который содержит 2920 наименований сутр, шастр и оригинальных сочинений средневековых китайских буддистов. При этом была задействована современная пунктуация - в древних и средневековых текстах она отсутствовала. Это огромная работа, равнозначная переводу текстов со средневекового китайского языка на современный. Издается множество комментариев к оригинальным сочинениям. Основные буддологические центры сосредоточены в Пекинском университете, где работает классик китайской буддологии Фан Литянь, а также на юге Китая - в Университете Шанхая, Нанкина, в Гонконге, на Тайване. Особо следует отметить Нанкинский университет, где трудятся самые именитые ученые, чьи труды известны во всем мире Хун Сюпин, Лай Юнхай, Ян Вэйчжун. Кроме того, отметим Центр буддологии АОН КНР, чьим директором является Ян Цзэнвэй.

Большую значимость источниковедческие исследования имеют в Монголии. Здесь одинаковое внимание уделяется источникам на тибетском и монгольском языках. Отдельных буддологических центров в современной Монголии нет, если не считать собственно буддийские центры при монастырях Зуун и Баруун Хурээ и Буддийский университет при монастыре Гандантэкчелинг, которые в настоящее время делают попытки издания собственных комментариев к сочинениям и отдельным разделам Ганджура и Данджура. Из светских учреждений следует отметить Институт философии АН МНР, Институт языка АН МНР, бывшую кафедру религиоведения, в настоящее время объединенную с кафедрой философии Монгольского государственного университета ${ }^{1}$.

Таким образом, сегодня в мировой буддологической науке, развивающейся в классическом направлении, сложились устойчивые тенденции, среди которых можно выделить следующие:

${ }^{1}$ В составлении доклада активное участие принимали сотрудники отдела философии, культурологии и религиоведения. Материалы по буддологии США и Европы предоставила И. С. Урбанаева, по тибетологии Китая - И. Р. Гарри, по Монголии - Л. Л. Абаева. 
1) большое внимание уделяется тибетским источникам, при этом продолжается сохраняться интерес и к источникам на китайском языке. Все это происходит на фоне ослабевающего внимания к источникам на санскрите и пали;

2) в контексте большого внимания к тибетским источникам популярностью пользуется озвученная тибетскими религиозными и научными деятелями версия об аутентичности тибетских источников, которые наиболее точно и полно передают изначальный смысл учения Будды;

3) концепция аутентичности тибетских текстов обусловила формирование индотибетской буддологии. Ключевые персоны, стоявшие у истоков индо-тибетской буддологии в США, - Ричард Хью Робинсон, Геше Лхундуб Сопа, Масатоши Нагатоми, Алекс Вэйман, Дж. Хопкинс;

4) благодаря деятельности тибетских лам в буддологии сложились два подхода к исследованию буддизма - внешний и внутренний. Внутренний означает, что буддийская философия и буддийская наука имеют своим главным предметом внутреннее - внутреннюю реальность, сознание. В другом смысле nang-pa означает «тот, кто принадлежит к внутреннему кругу», т. е. принимает буддийское прибежище (Триратна). С точки зрения буддизма, любой небуддийский познавательный подход - это «внешний» подход;

5) в современной буддологической науке США наметилась тенденция компаративистских исследований. В центре внимания компаративистских исследований стоят тибетские источники, которые сравниваются с санскритскими и китайскими, и это происходит в контексте поиска аутентичного буддизма, их концептуальной схожести. Сравнительное изучение тибетских и китайских источников происходит в контексте поиска разночтений и отличий;

6) помимо этих тенденций наметились и негативные, характеризующие ряд современных американских исследований в такой важной предметной области буддологии, как учение буддизма - использование чужих переводов со ссылкой на оригинал. Особенно широко используются источниковедческие работы тибетских авторов, живущих в США. Дело в том, что переведенный текст - это продукт конкретной личности, обладающей своеобразием изложения своих взглядов, своими способностями теоретического анализа, обусловленными ее интеллектом, мировоззренческой позицией, собственным уровнем знания. Использование такого перевода должно сопровождаться с обязательным указанием автора перевода. Это указывает на соавторство идей второго субъекта и первичного. Прямое указание на первоисточник дезориентирует читателя. Более того, такое использование готовых переводов порождает множество поверхностных дилетантских работ. Против таких работ выступал один из столпов российской буддологии И. П. Минаев еще в XIX в. К сожалению, они сегодня буквально наводняют буддологию. Этому во многом способствует Интернет;

7) в западной буддологии во многом благодаря деятельности Далай-ламы сложилась тенденция сравнительного изучения науки и буддизма. К этим исследованиям подключаются не только буддологи, но и ученые из других научных 
областей. Объектом сравнительного изучения главным образом становятся тексты на тибетском языке. Вместе с тем в области психологического знания большее внимание привлекают тексты на китайском языке.

Российская буддология в начальный период своего формирования была, как известно, ведущей в Европе. Мы не будем останавливаться на этой хорошо известной странице отечественной науки. Сегодня о буддизме пишут почти во всех университетских центрах от Калининграда до Владивостока, но это разрозненные, эпизодические явления. Многим из них присуща работа со вторичным материалом. Буддологических центров в России три - это Москва, Санкт-Петербург, Улан-Удэ.

В Москве в Институте философии и Институте востоковедения сохраняется изучение буддийских источников на санскрите. Ведущими учеными в этой области являются В. Г. Лысенко, В. П. Андросов, В. К. Шохин и А. А. Терентьев, Н. А. Канаева.

Изучение буддийских источников на китайском языке ведется в Институте Дальнего Востока. Здесь следует назвать имена М. В. Анашиной, С. А. Горбуновой. Кроме того, китайскими текстами занимаются В. В. Малявин и А. А. Маслов, но их интересы не сосредоточены только на буддизме, одинаковое внимание они уделяют даосизму и конфуцианству. Изучение буддизма по тибетским источникам представлены работами В. С. Дылыковой. В Санкт-Петербурге за последние годы, к великому сожалению, ушла из жизни плеяда блестящих ученых, таких как Л. Н. Меньшиков, А. С. Мартынов, Е. А. Торчинов, В. И. Рудой, М. Е. Ермаков, которые внесли огромный вклад в исследование буддизма по китайским и санскритским источникам. Из современных исследователей необходимо назвать имена П. Д. Ленкова, К. Ю. Солонина, Е. А. Островской-мл., Р. Крапивиной и др., исследующих буддизм по китайским и тибетским источникам.

На сегодняшний день в российской буддологии, к сожалению, отсутствует единый координационный центр. Такой центр пытались создать в 1980-х гг. Была проведена первая буддологическая конференция в Улан-Удэ, инициатором которой был В. И. Корнев, затем вторая буддологическая конференция в Москве. В 1986 г. в Улан-Удэ проведено совещание по проблемам буддийской философии. В тот период существовала определенная связь, единая информационная система. Важным фактором здесь являлся тот факт, что все мы печатались в одном издательстве «Наука», которое было определенным связующим звеном буддологических исследований. Сегодня буддология в России - это разрозненные исследования, которые не только не имеют связи, но даже не владеют достаточной информацией друг о друге.

Развитие буддологических исследований Института монголоведения, буддологии и тибетологии СО РАН сегодня развивается в русле фундаментальных научных исследований в соответствии с Программой фундаментальных научных исследований (ФНИ) государственных академий наук на 2013-2020 гг. Отделом философии, культурологии и религиоведения выдвинут проект научных исследований - «Комплексное исследование религиозно-философских, историко- 
культурных, социально-политических аспектов буддизма в традиционных и современных контекстах России и стран Центральной и Восточной Азии». Исследования отдела по данному проекту вполне соответствуют тем тенденциям, которые сформировались в мировой буддологии.

На сегодня в отделе сложилось четыре направления исследования буддизма: во-первых, изучение буддизма России по материалам Бурятии, во-вторых, тибетологические исследования буддизма, в-третьих, синологические (китаеведные), в-четвертых, исследования буддизма Монголии. В последнее время в орбиту буддологических исследований института все чаще включаются изыскания буддизма Японии, Кореи и Индии. Сотрудники отдела изучают письменные источники буддизма на китайском, тибетском, монгольском, бурятском, японском, корейском языках; исследуют историю буддизма России, Китая, Тибета, Монголии, Японии, Индии; философию и сотериологию китайского и тибетского буддизма; монастырскую историю буддизма; религиозную практику буддизма; место и роль буддизма в современных общественно-политических процессах.

Изначально отличительной особенностью буддологического направления в Бурятии было соединение академических методов с ресурсами буддийской учености (живой традицией), которая восходит к таким именам, как Б. Б. Барадин, П. И. Хадалов, Б. Д. Дандарон, Р. Е. Пубаев, К. М. Герасимова, Б. В. Семичов, П. Балданжапов, Ц. А. Дугарнимаев, Р. Н. Дугаров и др. Сегодня эти традиции продолжают развиваться в контексте конструктивного совмещения внутреннего и внешнего подходов к изучению буддизма. (Работы И. С. Урбанаевой наглядно демонстрируют принцип единства внешнего и внутреннего подходов.)

Характерной чертой институтской буддологии является не только прочная источниковедческая традиция, сопряженная с переводами и исследованием оригинальных текстов, но также применение широкого спектра методов философии и ряда гуманитарных наук (религиоведения, социологии, этнологии и др.) при опоре на знание базовых первоисточников на ведущих языках буддизма (китайский, тибетский, монгольский, бурятский, японский, корейский языки).

Сегодняшний уровень развития в ИМБТ СО РАН синологического и тибетологического направлений изучения буддизма, а также буддийской философии и практики позволяет развернуть крупномасштабные компаративистские исследования буддизма. Во-первых, чрезвычайно актуальным является развитие сравнительных сино-тибетских исследований буддизма (сравнение двух традиций махаяны - китайской и тибетской) как в историческом и источниковедческом, так и в содержательном философском, религиоведческом, культурологическом аспектах. Во-вторых, актуальным направлением компаративистских исследований является сравнение буддийской и западной философии. Хотя на Западе сегодня все чаще предпринимаются попытки сравнения буддизма с учениями западных философов разных эпох, тем не менее западным ученым не хватает знания буддийских первоисточников на языке оригинала и понимания буддизма «изнутри». Им мешают до сих пор господствующие европоцентристские стереотипы. Философы ИМБТ СО РАН имеют в сравнении с ними ряд преимуществ. 
В области китаеведной буддологии сегодня подготовлена почва для создания объемной, обобщающей монографии, охватывающей историю и учения китайского буддизма на протяжении всего его имперского периода. Практически по всем его эпохам и династийным периодам, за исключением юаньского и цинского, защищены докторские и кандидатские диссертации, опубликованы статьи, монографии.

В области тибетологической буддологии стоит задача участия сотрудников отдела в переводе Данджура и Ганджура на ведущие языки мира - европейские, а также китайский и русский. В русле этого проекта современные тибетские ученые в кооперации с наиболее авторитетными западными буддологами приступили к созданию вспомогательного научного аппарата, в частности, толкового словаря буддийской терминологии всех школ тибетского буддизма. Об этом проекте во время конференции «Буддизм в изменяющемся мире» говорил профессор Самдонг Ринпоче и предложил нашему институту присоединиться к этой работе.

В институте поддерживается инициатива Далай-ламы в области сравнительного изучения буддизма и науки. Проведен ряд конференций по этой теме, приуроченных ко дню рождения Далай-ламы. Издан сборник статей «Наука и буддизм» (Улан-Удэ, 2012).

Подводя итоги своему выступлению, отмечу, что при такой неплохой характеристике в области классической буддологии перед отделом стоит ряд актуальных задач. Одной из них является расширение международных связей в области буддологических исследований. Сегодня отделом налажено сотрудничество с учеными Монгольского государственного университета, Института философии МНР, Нанкинского государственного университета (КНР), Академии общественных наук КНР, Тартуского университета (Литва), Софийского университета (Болгария), Центрального института высших тибетологических исследований (г. Сарнатх, Индия). Вместе с тем дальнейшее успешное развитие буддологических исследований требует более широкого сотрудничества с учеными разных стран.

И, наконец, еще одной актуальной проблемой является пополнение отдела молодыми кадрами. Учеными отдела готовится достаточное количество молодых кандидатов и докторов наук, которые могут пополнить ряды ученых-буддологов. Уже сегодня они привлекаются к работе над выполнением проекта гранта РНФ «Буддизм в социально-политических и культурных процессах России, Внутренней и Восточной Азии: трансформации и перспективы». Хотелось бы более активно использовать их научный потенциал во благо отечественной буддологической науки.

Статья подготовлена в рамках государственного задания (проект XII.191.1.3 «Комплексное исследование религиозно-философских, историко-культурньх, соииальнополитических аспектов буддизма в традиционных и современных контекстах России и стран Центральной и Восточной Азии», номер госрегистрачии АААА-А17117021310263-7). 


\section{Питература}

Лысенко В. Г., Терентьев А. А., Шохин В. К. Ранняя буддийская философия. Философия джайнизма. - М.: Восточная литература РАН, 1994. - 383 с.

Самдонг Римпоче. Вызовы, которые принимают буддизм и тибетское сообщество в современном мире // Буддизм в контексте диалога культур. - Улан-Удэ, 2015. - С. 26-33.

Философия буддизма: энциклопедия / отв. ред. М. Т. Степанянц; Ин-т философии РАН. - М.: Вост. лит., 2011. - 1045 с. 